Check for updates

The BMJ

Cite this as: $B M J 2022 ; 376: 0528$ http://dx.doi.org/10.1136/bmj.0528 Published: 28 February 2022

\section{Covid-19: Incomplete lists of vulnerable patients left many unprotected, desperate, and afraid}

\author{
Ingrid Torjesen
}

Up-to-date registers of clinically vulnerable patients must be created to ensure that those who are most at risk during covid-19 and any future pandemics are protected and can access the support they need, a report from the All-Party Parliamentary Group (APPG) on Vulnerable Groups to Pandemics has recommended.

The report considered vulnerable people's experiences during the pandemic and makes 16 recommendations on what the government and the health service can do better to plan and prioritise extremely vulnerable patients during further covid-19 outbreaks and future pandemics. ${ }^{1}$

These tackle the format and content of information and guidance; access to medical services such as mental health support to help people deal with anxiety, fear, and isolation; provision of practical support such as food and finance when isolating; and the need for more research into how medical conditions make people more vulnerable to a threat and vaccines less protective.

At the launch of the report representatives of charities and patient groups described how the pandemic had left clinically vulnerable people feeling anxious, afraid, lonely, trapped, and desperate. They also described the "not on the list" scenario many had had to contend with, meaning they could not access priority services such as testing or support to isolate. There were still patients whose doctors recognised that they should be on the list fighting to get their condition recognised, said Susan Walsh, chief executive of Immunodeficiency UK. This means that, under the government's Living with Covid plans, they will no longer be able to access free testing. Lord Mendelsohn, co-chair of the APPG on Vulnerable Groups to Pandemics, said, "We should be more willing to allow the medical practitioners responsible for these patients to be able to overhaul computerised systems and find ways to make that happen."

When shielding advice was given in 2020 the term "clinically extremely vulnerable" was not commonly used and the shielding list was created using data from a variety of sources-GP records, hospital records, and other datasets-said Richard Vautrey, former chair of the BMA general practitioner's committee, who contributed to the report. "One of the problems was that we weren't sure what this infection was and how it was going to affect people," he said. "It wasn't as simple as one condition means that you're on the list and one condition means that you're not because, as we know, with many conditions there's a huge spectrum of severity."

He added that there were several lists for vulnerability and that someone considered vulnerable to flu would not necessarily be considered vulnerable to covid-19, which caused "confusion."

Lessons needed to be learnt, Vautrey said. "We do need to be led by experts who understand the condition that we're protecting people against, and then ensure that the data that are held in different systems are pooled in one place, so that it can be an accurate system that can be accessed rapidly."

The official terminology to identify people who needed to be protected had recently changed from clinically extremely vulnerable to

immunocompromised, Sal Brinton said, and it is unclear how many people this includes. "We have no idea, because no one is taking the lead," she said.

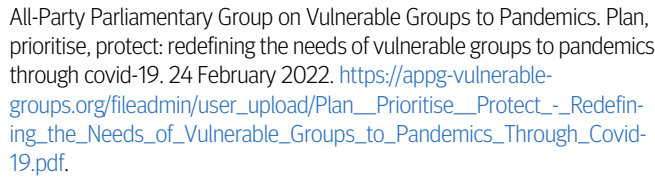

All-Party Parliamentary Group on Vulnerable Groups to Pandemics. Plan, prioritise, protect: redefining the needs of vulnerable groups to pandemics through covid-19. 24 February 2022. https://appg-vulnerablegroups.org/fileadmin/user_upload/Plan_Prioritise__Protect_-_Redefining_the_Needs_of_Vulnerable_Groups_to_Pandemics_Through_Covid19.pdf.

This article is made freely available for personal use in accordance with BMJ's website terms and conditions for the duration of the covid-19 pandemic or until otherwise determined by BMJ. You may download and print the article for any lawful, non-commercial purpose (including text and data mining) provided that all copyright notices and trade marks are retained. 